\title{
RESEARCH
}

Open Access

\section{Hypertension control among euvolemic hypertensive hemodialysis patients in Malaysia: a prospective follow-up study}

Amjad Khan ${ }^{1,2,3^{*}}$ (D) Amer Hayat Khan ${ }^{1,2}$, Azreen Syazril Adnan², Syed Azhar Syed Sulaiman', Saima Mushtaq ${ }^{4}$, Nafees Ahmad ${ }^{5}$ and Irfanullah Khan ${ }^{1,2}$

\begin{abstract}
Objectives: Existing literature does not provide enough information on evaluation of factors associated with pre-dialysis controlled hypertension among euvolemic hemodialysis (HD) patients. We conducted a study to evaluate the rate and factors influencing pre-dialysis controlled hypertension among euvolemic HD patients.

Design: A multicenter prospective follow-up study.

Setting: Tertiary care teaching hospital and its associated private dialysis centers.

Participants: This study included 145 euvolemic eligible hypertensive patients. Various sociodemographic, clinical factors and drugs were investigated and analyzed by using appropriate statistical methods to determine the factors influencing hypertension control among the study participants.

Results: On baseline visit, the mean pre-dialysis systolic and diastolic BP ( $\mathrm{mmHg})$ of study participants was $161.2 \pm 24$. and $79.21 \pm 11.8$ retrospectively, and 30 (20.6\%) patients were on pre-dialysis goal BP. At the end of the 6-months follow-up, the mean pre-dialysis systolic BP and diastolic BP $(\mathrm{mmHg})$ of the patients was $154.6 \pm 18.3$ and $79.2 \pm 11.8$ respectively, and 42 (28.9\%) were on pre-dialysis goal BP. In multivariate analysis, the use of calcium channel blockers (CCBs) was the only variable which had statistically significant association with pre-dialysis controlled hypertension at baseline $(\mathrm{OR}=7.530, p$-value $=0.001)$ and final $(\mathrm{OR}=8.988, p$-value $<0.001)$ visits.

Conclusions: In present study, the positive association observed between CCBs and controlled hypertension suggests that CCBs are effective antihypertensive drugs in the management of hypertension among euvolemic HD patients.

(Continued on next page)
\end{abstract}

\footnotetext{
* Correspondence: amjadkhan@qau.edu.pk

${ }^{1}$ Discipline of Clinical Pharmacy, School of Pharmaceutical Sciences, Universiti

Sains Malaysia, 11800 Penang, Malaysia

${ }^{2}$ Chronic Kidney Disease Resource Centre, School of Medical Sciences, Health

Campus, Universiti Sains Malaysia, 16150 Kubang Kerian, Kelantan, Malaysia

Full list of author information is available at the end of the article
}

(c) The Author(s). 2019 Open Access This article is distributed under the terms of the Creative Commons Attribution 4.0 International License (http://creativecommons.org/licenses/by/4.0/), which permits unrestricted use, distribution, and reproduction in any medium, provided you give appropriate credit to the original author(s) and the source, provide a link to the Creative Commons license, and indicate if changes were made. The Creative Commons Public Domain Dedication waiver (http://creativecommons.org/publicdomain/zero/1.0/) applies to the data made available in this article, unless otherwise stated. 
(Continued from previous page)

Strengths and limitations of this study:

- This study involved a group of patients from tertiary-level teaching hospital and its associated private dialysis centers of Malaysia.

- To the best of the authors' knowledge, this is the first study to assess the factors influencing pre-dialysis controlled hypertension in a cohort of 145 euvolemic HD patients in a Malaysian setting.

- For determining the factors influencing hypertenion control multivariate analysis was conducted.

- Being a prospective follow-up study, the findings of the present study need to be interpreted with caution since it is limited to only 6 months follow up.

- Nevertheless, a multicenter study with a large sample size and longer follow up time is needed to confirm the findings of the current study.

Keywords: Calcium channel blockers, Euvolemic, Hemodialysis, Hypertension

\section{Background}

Hypertension is common and often poorly controlled among hemodialysis (HD) patients. In fact, volume overload is considered as an important cause of hypertension where patients may remain hypertensive even after thrice weekly HD sessions. In such patients, non-volume mechanisms such as activation of the renin angiotensin system and/or sympatho-adrenal activities, are important contributors to hypertension [1-3]. Due to their safety, tolerability and good therapeutic efficacies, renin angiotensin aldosterone system (RAAS) inhibitors are also considered as the first line agents in the treatment of hypertension among HD patients [4]. The national kidney foundation disease outcomes quality initiative (KDOQI) guidelines also recommend the use of RAAS inhibitors among dialysis patients having diabetic and heart failures [5].

A literature suggests that systolic BP is associated with cardiovascular adverse events [6]. Studies by Moist et al. and Efrati et al. concluded that the use of angiotensin converting enzyme (ACE) inhibitors is associated with improved survival [7, 8]. In fact, blood pressure (BP) control and cardiovascular outcomes can be improved by combining ACE inhibitors and angiotensin receptor blockers (ARBs) therapies [9]. Calcium channel blockers (CCB)s and other vasodilators are also considered to be effective in managing BP where CCBs are often widely applied in patients with volume overload and can very useful for lowering the BP among HD patients [10]. A recent randomized controlled trial reported that amlodipine can lower systolic $\mathrm{BP} \sim 10$ $\mathrm{mmHg}$ as compared with placebo (7\% vs. $13 \%$, respectively) without introducing an intradialytic hypotension [11]. Nevertheless, there is limited literature available on the role of CCBs regarding the management of hypertension among HD patients.
Among the general population, studies investigating CCBs use indicated mixed findings regarding their effects on patient's outcome [12-18]. For example, the use of short acting dihydropyridines leads to a higher risk of developing myocardial infarction while the longer acting CCBs pose some mortality risks as also seen with the use of other antihypertensive medications [10]. Generally, CCBs are commonly prescribed to patients with end stage renal disease (ESRD), mainly for BP control though it may have different effects in ESRD patients [10]. CCBs inhibit vasoconstriction as well as both the hypertrophic and hyperplastic effects of angiotensin II and other mitogens on the mesangial and vascular smooth muscle cells by blocking calcium-dependent mechanisms [19-21]. The USA national clinical practice guideline (2005), recommended a pre-dialysis BP of less than $140 / 90 \mathrm{mmHg}$ and post-dialysis BP of less than 130/80 $\mathrm{mmHg}$ [22]. However, achieving these standards in clinical practice remains a challenge. In this study, an observational analysis to evaluate the factors influencing pre-dialysis controlled hypertension among euvolemic HD patients is conducted.

\section{Materials and methods \\ Study location and participants}

This was a multicenter, prospective follow-up study conducted among HD patients at Hospital Universiti Sains Malaysia (HUSM), which is a tertiary care hospital and its associated dialysis centers in Kelantan, Malaysia. All confirmed hypertensive HD patients between 1st April 2017 to 31st December 2017 who received anti-hypertensives and have to undergo dialysis three times a week were consecutively enrolled in the study. 


\section{Operational definitions}

\section{Hypertension}

According to KDOQI guidelines, pre-dialysis and postdialysis BP goals should be $<140 / 90 \mathrm{mmHg}$ and $<130 / 80$ $\mathrm{mmHg}$, respectively.

\section{Controlled hypertension}

Patients with a mean systolic/diastolic BP of $<130 / 80$ $\mathrm{mmHg}$ were considered as having controlled hypertension.

\section{Hypervolemia, Euvolemia and hypovolemia}

A multi-frequency $(5-1000 \mathrm{kHz})$ portable bioimpedance spectroscopy device (Body Composition Monitor, BCM, Fresenius Medical Care, Germany) was used to assess fluid status. The BCM-calculated overhydration $(\mathrm{OH})$ value was used as a fluid overload indicator. Accordingly, $\mathrm{OH}>1.1 \mathrm{~L}$ was categorized as fluid overload or hypervolemia. An $\mathrm{OH}$ value lower than the 10th percentile $(-1.1 \mathrm{~L})$ was defined as hypovolemia. An $\mathrm{OH}$ value of $\pm 1.0 \mathrm{~L}$ was defined as euvolemia, i.e., normal hydration status [23-25].

Patients with pre-dialytic hypotension (having a systolic BP less than $110 \mathrm{mmHg}$ ) or high BP $>200 / 100$ $\mathrm{mmHg}$ were excluded from the study. A total of 220 met the eligibility criteria and were included in the study
(Fig. 1). From this number, 75 hyper and hypovolemic patients were excluded. Finally, the pre-dialysis BP measurements and the effect of antihypertensive drugs on BP on 145 euvolemic patients were assessed. The study procedures were in accordance with the clinical practice guidelines for HD from National Kidney Foundation Kidney Disease Outcome Quality Initiative (NKF KDOQI) [26]. Diagnosis of cardiovascular disease and other comorbidities were based on documentation from patient's medical record. Patients with ischemic heart disease, heart failure and left ventricular hypertrophy were considered to have cardiovascular disease. We used the criteria based on advisory committee suggestions, extensive literature review, hypothetical possible association and nephrologist's suggestions i.e. If three consecutive $\mathrm{BCM}$ readings confirms the euvolemic state, then those patients are considered as euvolemic HD patients and we further proceeded them for hypertension evaluation.

\section{Data collection}

Both socio-demographic and clinical data were collected from the regularly updated Advanced Dialysis Nephrology Application Network (ADNAN) at the study sites (URL:

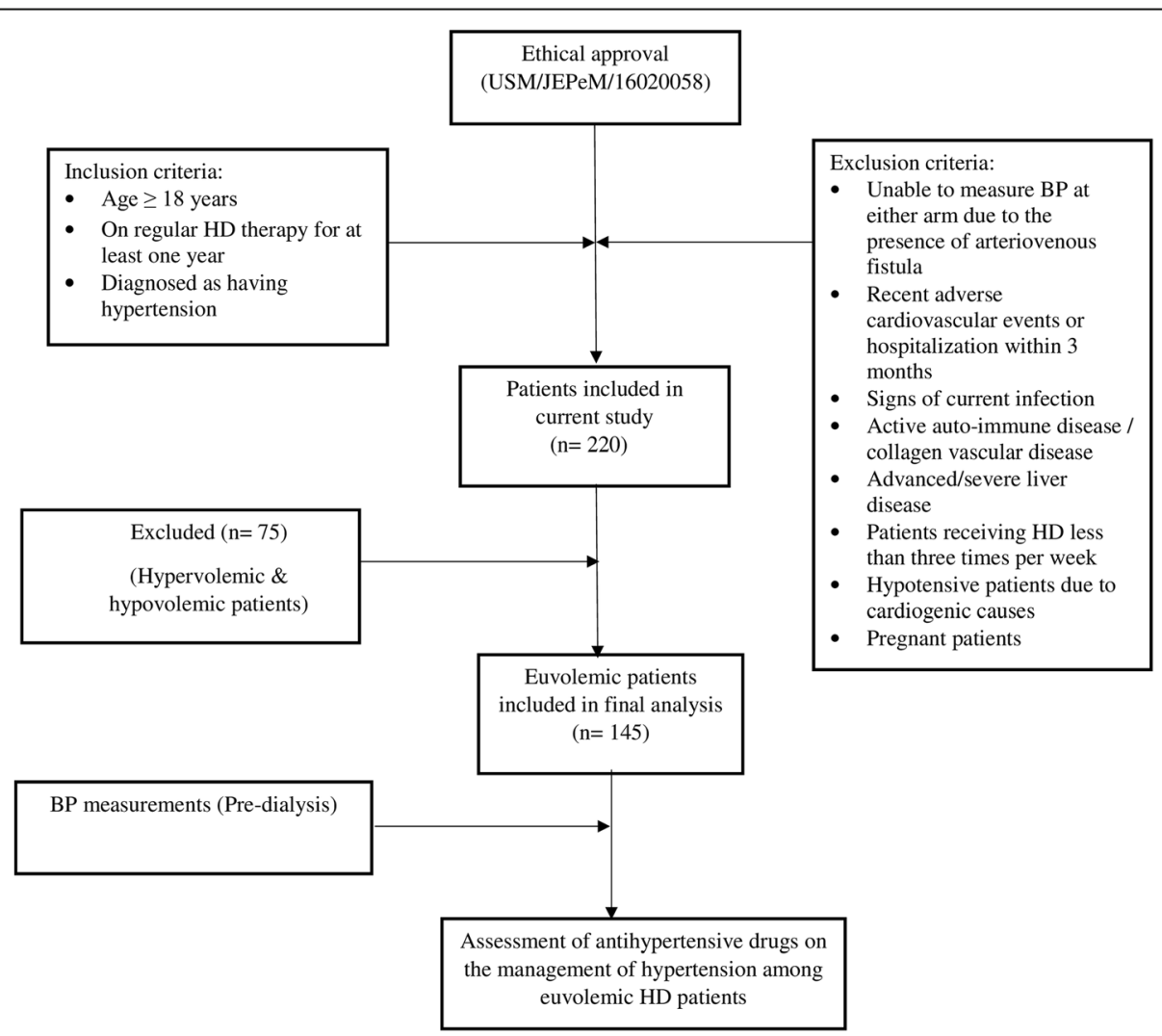

Fig. 1 Study Design 
Table 1 Baseline demographics and characteristics of euvolemic hemodialysis patients $(n=145)$

\begin{tabular}{|c|c|}
\hline Variables & No. (\%) \\
\hline \multicolumn{2}{|l|}{ Gender } \\
\hline Female & $75(51.7)$ \\
\hline Male & $70(48.3)$ \\
\hline Age mean $( \pm S D)$ & $58.68( \pm 9.857)$ \\
\hline \multicolumn{2}{|l|}{ Age group (years) } \\
\hline$<40$ & $7(4.8)$ \\
\hline $41-60$ & $83(57.2)$ \\
\hline$>60$ & $55(37.9)$ \\
\hline BMI mean $( \pm \mathrm{SD})$ & $23.908( \pm 4.3505)$ \\
\hline \multicolumn{2}{|l|}{ BMI classification } \\
\hline Underweight & $6(4.1)$ \\
\hline Normal & $90(62.1)$ \\
\hline Overweight & $42(29)$ \\
\hline Obese & $7(4.8)$ \\
\hline \multicolumn{2}{|l|}{ Education } \\
\hline Uneducated & $40(27.6)$ \\
\hline Educated & $105(72.4)$ \\
\hline \multicolumn{2}{|l|}{ Marital status } \\
\hline Single & $6(4.1)$ \\
\hline Married & $139(95.9)$ \\
\hline \multicolumn{2}{|l|}{ Ethnicity } \\
\hline Malay & $140(96.6)$ \\
\hline Others & $5(3.4)$ \\
\hline \multicolumn{2}{|l|}{ Smoking status } \\
\hline Current Smoker & $44(30.3)$ \\
\hline Non-Smoker & $101(69.7)$ \\
\hline \multicolumn{2}{|l|}{ Alcohol } \\
\hline Current drinker & $6(4.1)$ \\
\hline Non-drinker & $139(95.9)$ \\
\hline \multicolumn{2}{|l|}{ Drug addiction } \\
\hline Current Drug Addiction & $16(11)$ \\
\hline No Drug Addiction & $129(89)$ \\
\hline \multicolumn{2}{|l|}{ Employment } \\
\hline Unemployed & $77(53.1)$ \\
\hline Employed & $68(46.9)$ \\
\hline \multicolumn{2}{|l|}{ Years of dialysis } \\
\hline 1 year & $43(29.7)$ \\
\hline $2-4$ years & $57(39.3)$ \\
\hline$>5$ years & $45(31)$ \\
\hline \multicolumn{2}{|l|}{ Hemodialysis centers } \\
\hline Private & $84(57.9)$ \\
\hline NGO & $24(16.6)$ \\
\hline Governmental & $37(25.5)$ \\
\hline
\end{tabular}

Table 1 Baseline demographics and characteristics of euvolemic hemodialysis patients $(n=145)$ (Continued)

\begin{tabular}{ll}
\hline Variables & No. (\%) \\
\hline Vascular access & $135(93.1)$ \\
Fistula & $10(6.9)$ \\
Others & \\
Diabetes mellitus & $48(33.1)$ \\
No & $97(66.9)$ \\
Yes & \\
Cardiovascular diseases & $125(86.2)$ \\
No & $20(13.8)$ \\
Yes & \\
Cerebrovascular accident & $131(90.3)$ \\
No & $14(9.7)$ \\
Yes & \\
Hyperlipidemia & $125(86.2)$ \\
No & $20(13.8)$ \\
Yes & \\
Gouty arthritis & $127(87.6)$ \\
No & $18(12.4)$ \\
Yes & \\
Other comorbidities & \\
No & $104(71.7)$ \\
Yes & $41(28.3)$ \\
\hline
\end{tabular}

SD Standard deviation, BMI Body Mass Index, NGO

Non-governmental organization

aOther comorbidities: Blood clots, depression, asthma, osteoarthritis, pregnancy losses/birth defects and osteoporosis

http://www.microsemi.com.my/product/advanced-dialysis-nephrologist-application-network-adnan-system) using a standardized data collection form. Height, weight and $\mathrm{BP}$ were measured during the physical examination. Only a single calibrated manual sphygmomanometer was used to measure $\mathrm{BP}$ in all of the patients. A multi-frequency (5-1000 kHz) portable bioimpedance spectroscopy device (Body Composition Monitor, BCM, Fresenius Medical Care, Germany) was used to assess fluid status.

On the dialysis day, pre-dialysis BP was taken as a mean of three consecutive measurements with 5-min intervals. BP was recorded by a senior member of the nursing staff dedicated to the study. As per KDOQI guidelines, BP goals were defined as < 140/ 90 and $<130 / 80 \mathrm{mmHg}$ for pre-and post-dialysis respectively. Patients with a mean systolic/diastolic BP of $\geq 140 / 90 \mathrm{mmHg}$ were considered as having an uncontrolled hypertension. During the 6 months' follow-up, the mean pre-dialysis $\mathrm{BP}$ readings at baseline, $1,2,3,4,5$ and 6 months were recorded and the effects of antihypertensive drugs on pre-dialysis BP control were assessed. 


\section{Statistical analysis}

Statistical Package for Social Sciences (SPSS version 21, Chicago, USA) was used for data analysis. Means and standard deviations were calculated for continuous variables, whereas categorical variable are presented as frequencies and percentages. Chi-squared test was used to observe significance between categorical variables. Multivariate logistic regression analysis with the Wald statistical criteria was used to obtain a final model. A $p$-value of $<0.05$ was considered statistically significant. Relevant variables with a $p$-value $<0.25$ in the univariate analysis were included in the multivariate analysis. We confirmed the correlations among variables entered in the multivariate analysis. The results of multivariate analysis were presented as beta, standard error, $p$-value, adjusted odds ratio and $95 \%$ confidence interval. The fit of the model was assessed by Hosmer Lemeshow and overall classification percentage.

\section{Results}

The mean age of the study participants $(n=145)$ was 58.68 ( \pm 9.86$)$ years. The majority were females $(51.7 \%)$, 41-60 years old (57.2\%), of a normal body mass index (BMI) (62.1\%) and on dialysis for more than 5 years (31\%). Since the study was conducted in the Malaysian state of Kelantan, most patients were of Malay ethnicity (96.6\%) (Table 1).

Table 2 Euvolemic hemodialysis patient's antihypertensive medication and comorbidities $(n=145)$

\begin{tabular}{ll}
\hline Patient variables & No. (\%) \\
\hline Antihypertensive medication & $12(8.3)$ \\
ACE-I & $36(24.8)$ \\
ARBs & $43(29.7)$ \\
CCBs & $6(4.1)$ \\
Alpha antagonist & $42(29)$ \\
Beta antagonist & $41(28.3)$ \\
Diuretics & $15(10.3)$ \\
Antihypertensive combination therapy & \\
Co-morbid conditions & $118(81.3)$ \\
Hypertension & $97(66.9)$ \\
Diabetes mellitus & $20(13.8)$ \\
Cardiovascular diseases & $14(9.7)$ \\
Cerebrovascular accident & $20(13.8)$ \\
Hyperlipidemia & $18(12.4)$ \\
Gouty arthritis & $41(28.3)$ \\
Other comorbidities &
\end{tabular}

$A C E-I$ Angiotensin converting enzyme inhibitors, $A R B$ s Angiotensin receptor blockers, CCBs Calcium channel blockers, a Other comorbidities: Blood clots, depression, asthma, osteoarthritis, pregnancy losses/birth defects and osteoporosis
The most common comorbidities were hypertension $(n=118,81.3 \%)$ and diabetes $(n=97,66.9 \%)$. Calcium channel blockers $(n=43,29.7 \%)$ was the most prescribed antihypertensive followed by beta antagonist $(n=42,29 \%)$. Table 2 gives an account for euvolemic hemodialysis patients comorbid conditions and antihypertensive medication.

\section{Overall blood pressure changes}

At the baseline visit, the mean pre-dialysis systolic BP was $161.2 \pm 24.9 \mathrm{mmHg}$ while pre-dialysis diastolic BP was $79.21 \pm 11.8 \mathrm{mmHg}$ at baseline. At the end of the 6-months follow-up, the mean pre-dialysis systolic BP was $154.6 \pm 18.3 \mathrm{mmHg}$ giving a change in $\mathrm{BP}$ of -6.6 $\mathrm{mmHg}$. Similarly, pre-dialysis diastolic BP which was $79.21 \pm 11.8 \mathrm{mmHg}$ at baseline, dropped to $75.0 \mathrm{mmHg}$ $\pm 7.2 \mathrm{mmHg}$ at the end of study; a difference of -4.2 $\mathrm{mmHg}$. The mean pulse rate was $78 \pm 13.9$ beats per $\min$ at baseline which decreased to $74.5 \pm 10.4$. The mean baseline interdialytic weight gain was $1.8 \pm 0.8 \mathrm{~kg}$ with only $1.5 \pm 0.5 \mathrm{~kg}$ mean interdialytic weight gain at the end of study (Table 3).

Pre-dialysis BP variations of study duration are presented in graphical form in Fig. 2. There is a linear decrease in both mean systolic and diastolic BP from baseline towards sixth month.

\section{Overall mean blood pressure readings of all visits of study participants}

At the end of 6-month patient follow-up, the mean readings of all visits were calculated. The mean pre-dialysis systolic BP of all visits was $157.4 \pm 2.2 \mathrm{mmHg}$ and pre-dialysis diastolic BP was $77.0 \pm 1.4 \mathrm{mmHg}$. Mean pulse rate was $76.1 \pm 1.2$ beats/min and mean interdialytic weight gain was reported as $1.5 \pm 0.1 \mathrm{~kg}$ at the end of study. Table 4 provides the overall mean BP readings.

\section{Univariate and multivariate analysis (baseline)}

On baseline visit, a total of $30(20.6 \%)$ patients were on pre-dialysis goal BP of $<130 / 80 \mathrm{mmHg}$. Upon univariate binary logistic regression analysis, the associations observed between various independent variables and pre-dialysis controlled hypertension at baseline visit are given in (Table 5).

In the multivariate logistic regression analysis, the only variable which was statistically significant associated with pre-dialysis controlled hypertension was the use of CCBs $(\mathrm{OR}=7.530, p$-value $=0.001)($ Table 5$)$.

\section{Univariate and multivariate analysis (upon study completion)}

Upon final visit, a total of $42(28.9 \%)$ patients were on pre-dialysis goal BP of $<130 / 80 \mathrm{mmHg}$. Upon univariate binary logistic regression analysis, the associations 
Table 3 Blood Pressure readings during the course of study $(n=145)$

\begin{tabular}{llllllll}
\hline Variables & $\begin{array}{l}\text { Baseline } \\
\text { Mean }( \pm S D)\end{array}$ & $\begin{array}{l}\text { 1st month } \\
\text { Mean } \\
( \pm S D)\end{array}$ & $\begin{array}{l}\text { 2nd month } \\
\text { Mean } \\
( \pm S D)\end{array}$ & $\begin{array}{l}\text { 3rd month } \\
\text { Mean } \\
( \pm S D)\end{array}$ & $\begin{array}{l}\text { 4th month } \\
\text { Mean } \\
( \pm S D)\end{array}$ & $\begin{array}{l}5 \text { th } \\
\text { Month } \\
\text { Mean } \\
( \pm S D)\end{array}$ & $\begin{array}{l}\text { 6th } \\
\text { Month } \\
\text { Mean } \\
( \pm S D)\end{array}$ \\
\hline Pre-dialysis systolic BP & $161.2( \pm 24.9)$ & $159.2( \pm 23.3)$ & $158.0( \pm 21.9)$ & $157.1( \pm 21.0)$ & $156.4( \pm 20.1)$ & $155.7( \pm 19.5)$ & $154.6( \pm 18.3)$ \\
Pre-dialysis diastolic BP & $79.2( \pm 11.8)$ & $78.3( \pm 10.7)$ & $77.5( \pm 9.5)$ & $77.2( \pm 9.1)$ & $76.5( \pm 8.4)$ & $75.9( \pm 7.8)$ & $75.0( \pm 7.2)$ \\
Pre-dialysis pulse rate & $78.0( \pm 13.9)$ & $77.2( \pm 12.9)$ & $76.6( \pm 12.0)$ & $76.1( \pm 11.4)$ & $75.7( \pm 11.2)$ & $75.15( \pm 10.8)$ & $74.5( \pm 10.4)$ \\
Interdialytic weight gain & $1.8( \pm 0.8)$ & $1.8( \pm 0.7)$ & $1.6( \pm 0.6)$ & $1.5( \pm 0.5)$ & $1.6( \pm 0.6)$ & $1.4( \pm 0.5)$ & $1.3( \pm 0.4)$ \\
\hline
\end{tabular}

observed between various independent variables and pre-dialysis controlled hypertension at final visit are given in Table 6.

In the multivariate logistic regression analysis, the only variable which had statistically significant association with pre-dialysis controlled hypertension was prescription of CCBs (OR $=8.988, p$-value $=<0.001)$. Those patients who were receiving CCBs had significantly high rate of hypertension control than those who were not receiving it (Table 6).

\section{Discussion}

Although the use of ACE inhibitors and ARBs are associated with reduction of $\mathrm{BP}$ in HD patients [8] limited literature is available on the evaluation of factors associated with pre-dialysis controlled hypertension among euvolemic hemodialysis patients. This is seen even though the prevalence of uncontrolled hypertension in HD patients as defined based on the recommendations by KDOQI of achieving a pre-HD systolic BP $<140 \mathrm{mmHg}$ and a post-HD systolic BP $<130 \mathrm{mmHg}$, [5] is reported to be high (80-90\%) [27].
The probability of combining two or more medications to achieve good targeted BP can be reduced in certain ethnic groups who are relatively more responsive to certain classes of antihypertensive drugs used for lowering BP. The fixed-dose combination therapy of certain drugs such as a CCB and ACE inhibitors are known to confer some beneficial complementary physiologic action, lower side-effect profiles, improve tolerability, compliance, and salutary effect on target organs at a relatively lower cost. To date, different types of fixed-dose combination therapies for lowering $\mathrm{BP}$ are available and are commonly employed for clinical use [28].

In our study, the observed positive association between prescription of CCB and predialysis controlled hypertension is similar to the findings of a randomized controlled trial on nitrendipine [10]. Similarly, the findings of another retrospective study in $\mathrm{HD}$ patients suggest that the use of CCBs are associated with a lower risk of mortality [29] indicating the benefits of administering CCB in HD patients. In contrast, London et al in a small clinical trial reported that a CCB named nitrendipine failed to reduce left ventricular hypertrophy as compared to the use of an $\mathrm{ACE}$

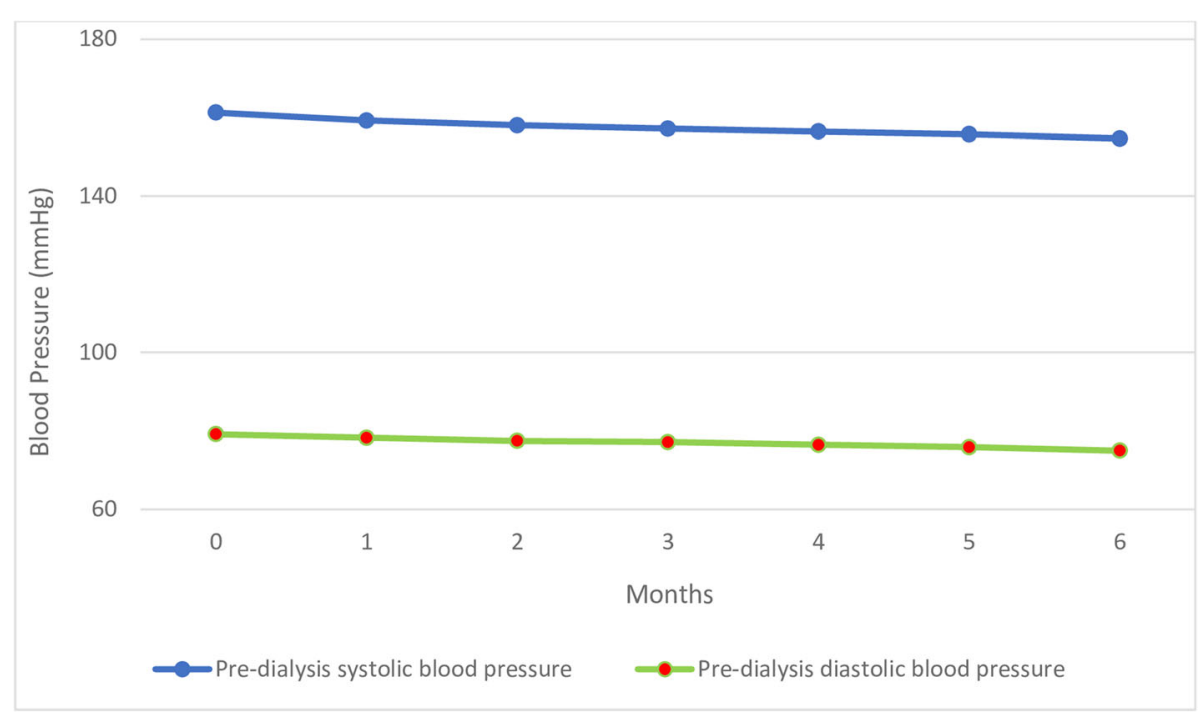

Fig. 2 Graphical representation of pre-dialysis blood pressure variations during the six month's follow up 
Table 4 Overall mean BP readings during the course of study $(n=145)$

\begin{tabular}{ll}
\hline Variables & Mean $( \pm$ SD $)$ \\
\hline Pre-dialysis systolic (mean of all BP readings) & $157.4( \pm 2.2)$ \\
Pre-dialysis diastolic (mean of all BP readings) & $77.0( \pm 1.4)$ \\
Pre-dialysis pulse rate (mean of all readings) & $76.1( \pm 1.2)$ \\
Interdialytic weight gain (mean of all readings) & $1.5( \pm 0.1)$ \\
\hline
\end{tabular}

inhibitor (perindopril) despite having effectively lowered BP to similar levels [30]. Nevertheless, since CCBs are not removed by HD, no additional post-dialysis dosing is required. Moreover, a once daily dosing of most CCBs make them attractive for use in HD patients [31] which warrants our further investigation.

The results from an observational study by Kestenbaum et al demonstrated that CCBs contribute to a $21 \%$ lower risk of all-cause mortality and $26 \%$ cardiovascular specific mortality [11]. In addition, CCBs exhibit a variety of other potential therapeutic properties in HD patients. Vascular smooth muscle relaxation, better BP control and attenuation of heart rate as well as contractility are among the specifically important parameters for $\mathrm{HD}$ patients who have high incidence of hypertension and left ventricular hypertrophy $[32,33]$ are all purported mechanisms of action of CCBs which are useful.

A multicenter prospective study [34] conducted in Japan found that the use of benidipine, a dihydropyridine derivative calcium antagonist, alone or when added to ACE inhibitors reduced BP less than $150 / 90 \mathrm{mmHg}$ in almost $100 \%$ patients within a month which is similar to the findings in our study. It has been reported that treatment of a group of patients with calcium antagonists do not affect urinary protein excretion, although proteinuria is significantly reduced in patients treated with ACE inhibitor. However, it was noted that although CCBs do not affect proteinuria in the treated patients, they could slow down the progression of renal insufficiency while decreasing the BP significantly [32]. Similarly, Zucchelli et al. [35] in their prospective, randomized controlled trial showed the influence of captopril (an ACE inhibitor) and nifedipine (a CCB) on BP, renal insufficiency progression and proteinuria for three consecutive years found that both treatments exhibited similar effects on the progression rate of renal failure with similar reduction in BP seen with no significant reduction in proteinuria. In addition to these results, the Systolic Hypertension in Europe (Syst-Eur) Trial (1999) demonstrated that dihydropyridine-based antihypertensive treatment is particularly beneficial in older diabetic patients with isolated systolic hypertension [36]. Taken together, the results from the current study indicates the good potential of CCBs.
In agreement to our findings, another multicenter trial [37] also indicated a rapid reduction in BP when patients were treated with CCBs. These results further support our point of view that CCBs should be incorporated into the therapy of elderly hypertensive patients with chronic renal insufficiency with careful monitoring of BP. Similarly, CCBs have been found to be effective in cases of renal failure where patients tend to exhibit significant resistance to antihypertensive medications [38]. Moreover, studies in several animal models of progressive renal failure have shown that in addition to their antihypertensive effects, CCBs have other established advantages where like other vasodilating agents, they neither cause sodium and water retention nor hyperkalemia as usually seen with ACE inhibitors administrations [39]. However, at the moment it may not be evidently claimed that the results obtained from the referred animal models could be extrapolated to humans [40].

In addition to the above, CCBs are safe and have effective roles in treating or mitigating various complications pertaining to cardiovascular disorders and renal diseases in diabetic patients. For instance, the findings of a placebo-controlled double-blind trial revealed that antihypertensive treatment employing a dihydropyridine $\mathrm{CCB}$ indicated some beneficial effects in older diabetic patients as compared to the non-diabetic patients which reject the hypothesis that the use of long- acting CCBs is harmful in older diabetic patients [35].

There was similar reported cardiovascular benefit in patients who receive nitrendipine alone as opposed to the use of either enalapril or hydrochlorothiazide (or both nitrendipine and either enalapril or hydrochlorothiazide) [41]. It has been reported in many outcome trials that the relative benefit of antihypertensive therapy has been similar, but there is a wide difference in the absolute benefit according to the number of outcomes observed in the control group [42]. In a randomized trial [43], it has been reported that patients receiving fosinopril experienced a significantly lower number of acute myocardial infarction or stroke or angina pectoris (14 of 189 patients, vs. 27 of 191 treated with amlodipine). However, this was an open randomized controlled trial and the adverse effects were recorded by asking patients whether they had been hospitalized or had any other discomfort.

In keeping with our findings, the Hypertension Optimal Treatment Trial [15] revealed that BP control can be achieved (target diastolic BP, $80 \mathrm{mmHg}$ rather than $90 \mathrm{mmHg}$ ) with the use of felodipine as the first-line agent, and resulted in lower rates of all cardiovascular events in 1501 study participants with diabetes (relative risk, 0.49 ; $95 \%$ confidence interval, 0.29 to 0.81 ; 
Table 5 Univariate and multivariate analysis of factors associated with pre-dialysis controlled hypertension at baseline $(n=145)$

\begin{tabular}{|c|c|c|c|c|c|c|}
\hline \multirow[t]{2}{*}{ Variables } & \multicolumn{2}{|c|}{$\begin{array}{l}\text { Patients with pre-dialysis controlled hypertension at baseline } \\
\text { Number (\%) }\end{array}$} & \multirow[t]{2}{*}{$\begin{array}{l}\text { Univariate analysis } \\
\text { OR }(95 \% \mathrm{Cl})\end{array}$} & \multirow[t]{2}{*}{$p$-value } & \multirow[t]{2}{*}{$\begin{array}{l}\text { Multivariate analysis } \\
\text { OR }(95 \% \mathrm{Cl})\end{array}$} & \multirow[t]{2}{*}{$p$-value } \\
\hline & Yes & No & & & & \\
\hline \multicolumn{7}{|l|}{ Gender } \\
\hline Female & $18(24)$ & $57(76)$ & Reference & & & \\
\hline Male & $12(17.1)$ & $58(82.9)$ & $0.655(0.289-1.483)$ & 0.310 & & \\
\hline \multicolumn{7}{|l|}{ Age } \\
\hline$\leq 40$ & $1(14.3)$ & $6(85.7)$ & Reference & & & \\
\hline $41-60$ & $15(18.1)$ & $68(81.9)$ & $1.324(0.148-11.821)$ & 0.802 & & \\
\hline$>60$ & $14(25.5)$ & $41(74.5)$ & $2.049(0.227-18.531)$ & 0.523 & & \\
\hline \multicolumn{7}{|l|}{$\mathrm{BMI}$} \\
\hline Underweight & $3(50)$ & $3(50)$ & Reference & & Reference & \\
\hline Normal & $17(18.9)$ & $73(81.1)$ & $0.233(0.043-1.256)$ & 0.090 & $0.597(0.080-4.470)$ & 0.615 \\
\hline Overweight & $7(16.7)$ & 35 (83.3) & $0.200(0.033-1.203)$ & 0.079 & $0.378(0.036-3.951)$ & 0.417 \\
\hline Obese & $3(42.9)$ & $4(57.1)$ & $0.750(0.084-6.710)$ & 0.797 & $1.737(0.109-1.851)$ & 0.268 \\
\hline \multicolumn{7}{|l|}{ Smoking status } \\
\hline Current Smoker & $8(18.2)$ & $36(81.8)$ & Reference & & & \\
\hline Non-Smoker & $22(21.8)$ & $79(78.2)$ & $1.253(0.509-3.083)$ & 0.623 & & \\
\hline \multicolumn{7}{|l|}{ Drug addiction } \\
\hline Current drug addiction & $5(31.3)$ & $11(68.8)$ & Reference & & & \\
\hline No drug addiction & $25(19.4)$ & $104(80.6)$ & $0.529(0.169-1.660)$ & 0.275 & & \\
\hline \multicolumn{7}{|l|}{ Hemodialysis centers } \\
\hline Private & $16(19)$ & $68(81)$ & Reference & & Reference & \\
\hline NGO & $3(12.5)$ & $21(87.5)$ & 0.607 (0.161-2.288) & 0.461 & $0.448(0.109-1.851)$ & 0.268 \\
\hline Governmental & $11(29.7)$ & $26(70.3)$ & $1.798(0.738-4.382)$ & 0.197 & 0.959 (0.299-3.077) & 0.944 \\
\hline \multicolumn{7}{|l|}{ Vascular access } \\
\hline Fistula & $28(20.7)$ & $107(79.3)$ & Reference & & & \\
\hline Others & $2(20)$ & $8(80)$ & $0.955(0.192-4.753)$ & 0.956 & & \\
\hline \multicolumn{7}{|l|}{ Diabetes mellitus } \\
\hline No & $10(20.8)$ & $38(79.2)$ & Reference & & & \\
\hline Yes & $20(20.6)$ & 77 (79.4) & $0.987(0.421-2.316)$ & 0.976 & & \\
\hline \multicolumn{7}{|l|}{ Cardiovascular diseases } \\
\hline No & $26(20.8)$ & $99(79.2)$ & Reference & & & \\
\hline Yes & $4(20)$ & $16(80)$ & $0.952(0.293-3.091)$ & 0.935 & & \\
\hline \multicolumn{7}{|l|}{ Cerebrovascular accident } \\
\hline No & 27 (20.6) & $104(79.4)$ & Reference & & & \\
\hline Yes & $3(21.4)$ & 11 (78.6) & $1.051(0.274-4.032)$ & 0.943 & & \\
\hline \multicolumn{7}{|l|}{ Hyperlipidemia } \\
\hline No & $30(24)$ & $95(76)$ & Non-computable & & & \\
\hline Yes & - & $20(100)$ & & - & & \\
\hline \multicolumn{7}{|l|}{ Gouty arthritis } \\
\hline No & $29(22.8)$ & $98(77.2)$ & Reference & & Reference & \\
\hline Yes & $1(5.6)$ & $17(94.4)$ & $0.199(0.25-1.558)$ & 0.124 & $0.304(0.033-2.770)$ & 0.291 \\
\hline
\end{tabular}


Table 5 Univariate and multivariate analysis of factors associated with pre-dialysis controlled hypertension at baseline $(n=145)$ (Continued)

\begin{tabular}{|c|c|c|c|c|c|c|}
\hline \multirow[t]{2}{*}{ Variables } & \multicolumn{2}{|c|}{$\begin{array}{l}\text { Patients with pre-dialysis controlled hypertension at baseline } \\
\text { Number (\%) }\end{array}$} & \multirow[t]{2}{*}{$\begin{array}{l}\text { Univariate analysis } \\
\text { OR }(95 \% \mathrm{Cl})\end{array}$} & \multirow[t]{2}{*}{$p$-value } & \multirow[t]{2}{*}{$\begin{array}{l}\text { Multivariate analysis } \\
\text { OR }(95 \% \mathrm{Cl})\end{array}$} & \multirow[t]{2}{*}{$p$-value } \\
\hline & Yes & No & & & & \\
\hline \multicolumn{7}{|c|}{ Others comorbidities $^{a}$} \\
\hline No & $18(17.3)$ & $86(82.7)$ & Reference & & Reference & \\
\hline Yes & $12(29.3)$ & $29(70.7)$ & $1.977(0.851-4.593)$ & 0.113 & $2.307(0.851-6.260)$ & 0.101 \\
\hline \multicolumn{7}{|l|}{ ACE-I } \\
\hline No & $30(22.6)$ & $103(77.4)$ & Non-Computable & & & \\
\hline Yes & - & $12(100)$ & & - & & \\
\hline \multicolumn{7}{|l|}{ ARB } \\
\hline No & $20(18.3)$ & $89(81.7)$ & Reference & & Reference & \\
\hline Yes & $10(27.8)$ & $26(72.2)$ & $1.712(0.713-4.109)$ & 0.229 & $3.436(0.965-12.238)$ & 0.061 \\
\hline \multicolumn{7}{|l|}{$\mathrm{CCB}$} \\
\hline No & $13(12.7)$ & 89 (87.3) & Reference & & Reference & \\
\hline Yes & $17(39.5)$ & $26(60.5)$ & $4.476(1.925-10.411)$ & 0.001 & $7.530(2.413-23.498)$ & 0.001 \\
\hline \multicolumn{7}{|l|}{ Alpha antagonist } \\
\hline No & $27(19.4)$ & 112 (80.6) & Reference & & Reference & \\
\hline Yes & $3(50)$ & $3(50)$ & $4.148(0.793-21.698)$ & 0.092 & $4.049(0.510-32.120)$ & 0.186 \\
\hline \multicolumn{7}{|l|}{ Beta antagonist } \\
\hline No & 19 (18.4) & $84(81.6)$ & Reference & & & \\
\hline Yes & $11(26.2)$ & $31(73.8)$ & 1.569 (0.671-3.667) & 0.299 & & \\
\hline \multicolumn{7}{|l|}{ Diuretics } \\
\hline No & $23(22.1)$ & $81(77.9)$ & Reference & & & \\
\hline Yes & $7(17.1)$ & $34(82.9)$ & $0.725(0.284-1.849)$ & 0.501 & & \\
\hline \multicolumn{7}{|c|}{ Other combination of antihypertensives } \\
\hline No & $27(20.8)$ & $103(79.2)$ & Reference & & & \\
\hline Yes & $3(20)$ & $12(80)$ & $0.954(0.251-3.621)$ & 0.944 & & \\
\hline \multicolumn{7}{|l|}{ Type of therapy } \\
\hline Mono-therapy & $15(19)$ & $64(81)$ & Reference & & & \\
\hline Multi-therapy & $15(22.7)$ & $51(77.3)$ & $1.255(0.561-2.806)$ & 0.580 & & \\
\hline \multicolumn{7}{|l|}{ Statins } \\
\hline No & $8(20)$ & $32(80)$ & Reference & & & \\
\hline Yes & $22(21)$ & $83(79)$ & $1.060(0.428-2.624)$ & 0.899 & & \\
\hline \multicolumn{7}{|l|}{ Phosphate binders } \\
\hline No & $5(27.8)$ & $13(72.2)$ & Reference & & & \\
\hline Yes & $25(19.7)$ & $102(80.3)$ & $0.637(0.208-1.954)$ & 0.431 & & \\
\hline
\end{tabular}

Analysis: Univariate and Multivariate binary logistic regression analysis. All variables with $p$-value $<0.25$ will be included in the multivariate analysis. OR Odds ratio, $\mathrm{Cl}$ confidence interval, BMI Body mass index, NGO Non-governmental organization, ${ }^{\mathrm{a}}$ Other comorbidities: Blood clots, depression, asthma, osteoarthritis, pregnancy losses/birth defects and osteoporosis. ACE-I Angiotensin converting enzyme inhibitors, ARB Angiotensin receptor blocker, CCB Calcium channel blocker

$p=0.005)$ but not in the overall study participants of 18,790 patients (relative risk, 0.93 ; 95\% confidence interval, 0.78 to $1.12 ; p=0.50$ ). Similarly, the effects of 5 to $20 \mathrm{mg} /$ day of manidipine, a dihydropyridine-type CCB on seventy- one renal impairment hypertensive patients on their BPs and renal functions were investigated for more than 48 weeks [37]. In our study BP was well controlled in $25(58.1 \%)$ patients out of 43 patients thus highlighting the potential benefits of CCBs in euvolemic hypertensive HD patients. Therefore, careful selection of antihypertensive drugs in these special group of patients are recommended. 
Table 6 Univariate and multivariate analysis of factors associated with pre-dialysis controlled hypertension upon study completion $(n=145)$

\begin{tabular}{|c|c|c|c|c|c|c|}
\hline \multirow[t]{2}{*}{ Variables } & \multicolumn{2}{|c|}{$\begin{array}{l}\text { Patients with pre-dialysis controlled } \\
\text { hypertension on final visit } \\
\text { Number (\%) }\end{array}$} & \multirow[t]{2}{*}{$\begin{array}{l}\text { Univariate analysis } \\
\text { OR }(95 \% \mathrm{Cl})\end{array}$} & \multirow[t]{2}{*}{$\begin{array}{l}p- \\
\text { value }\end{array}$} & \multirow[t]{2}{*}{$\begin{array}{l}\text { Multivariate } \\
\text { analysis } \\
\text { OR }(95 \% \mathrm{Cl})\end{array}$} & \multirow[t]{2}{*}{$\begin{array}{l}p^{-} \\
\text {value }\end{array}$} \\
\hline & Yes & No & & & & \\
\hline \multicolumn{7}{|l|}{ Gender } \\
\hline Female & $20(26.7)$ & $55(73.3)$ & Reference & & & \\
\hline Male & $22(31.4)$ & $48(68.6)$ & $1.260(0.614-2.586)$ & 0.528 & & \\
\hline \multicolumn{7}{|l|}{ Age } \\
\hline$\leq 40$ & $3(42.9)$ & $4(57.1)$ & Reference & & & \\
\hline $41-60$ & $22(26.5)$ & $61(73.5)$ & $0.481(0.100-2.321)$ & 0.362 & & \\
\hline$>60$ & $17(30.9)$ & $38(69.1)$ & $0.596(0.120-2.962)$ & 0.527 & & \\
\hline \multicolumn{7}{|l|}{ BMl } \\
\hline Underweight & $3(50)$ & $3(50)$ & Reference & & Reference & \\
\hline Normal & $22(24.4)$ & 68 (75.6) & $0.324(0.061-1.720)$ & 0.186 & $0.809(0.123-5.330)$ & 0.826 \\
\hline Overweight & $13(31)$ & $29(69)$ & $0.448(0.080-2.526)$ & 0.363 & $0.705(0.084-5.927)$ & 0.747 \\
\hline Obese & $4(57.1)$ & $3(42.9)$ & $1.333(0.149-11.929)$ & 0.797 & $4.775(0.352-64.836)$ & 4.775 \\
\hline \multicolumn{7}{|l|}{ Smoking status } \\
\hline Current Smoker & $12(27.3)$ & $32(72.7)$ & Reference & & & \\
\hline Non-Smoker & $30(29.7)$ & $71(70.3)$ & $1.127(0.512-2.480)$ & 0.767 & & \\
\hline \multicolumn{7}{|l|}{ Drug addiction } \\
\hline Current drug addiction & $8(50)$ & $8(50)$ & Reference & & Reference & \\
\hline No drug addiction & $34(26.4)$ & $95(73.6)$ & $0.358(0.125-1.028)$ & 0.056 & $0.492(0.129-1.870)$ & 0.298 \\
\hline \multicolumn{7}{|l|}{ Hemodialysis centers } \\
\hline Private & $20(23.8)$ & $64(76.2)$ & Reference & & Reference & \\
\hline NGO & $7(29.2)$ & $17(70.8)$ & $1.318(0.478-3.630)$ & 0.594 & $1.130(0.302-4.224)$ & 0.856 \\
\hline Governmental & $15(40.5)$ & $22(59.5)$ & $2.182(0.955-4.985)$ & 0.064 & 1.909 (0.601-6.062) & 0.273 \\
\hline \multicolumn{7}{|l|}{ Vascular access } \\
\hline Fistula & $38(28.1)$ & 97 (71.9) & Reference & & & \\
\hline Others & $4(40)$ & $6(60)$ & $1.702(0.455-6.368)$ & 0.430 & & \\
\hline \multicolumn{7}{|l|}{ Diabetes mellitus } \\
\hline No & $18(37.5)$ & $30(62.5)$ & Reference & & Reference & \\
\hline Yes & $24(24.7)$ & $73(75.3)$ & $0.548(0.260-1.154)$ & 0.113 & $0.415(0.156-1.105)$ & 0.078 \\
\hline \multicolumn{7}{|l|}{ Cardiovascular diseases } \\
\hline No & $26(20.8)$ & $99(79.2)$ & Reference & & & \\
\hline Yes & $4(20)$ & $16(80)$ & $0.793(0.269-2.340)$ & 0.674 & & \\
\hline \multicolumn{7}{|l|}{ Cerebrovascular accident } \\
\hline No & $37(29.6)$ & $88(70.4)$ & Reference & & & \\
\hline Yes & $5(25)$ & $15(75)$ & $0.643(0.170-2.434)$ & 0.516 & & \\
\hline \multicolumn{7}{|l|}{ Hyperlipidemia } \\
\hline No & $41(32.8)$ & $84(67.2)$ & Reference & & & \\
\hline Yes & $7(35.0)$ & $13(65)$ & $0.830(0.730-2.903)$ & 0.830 & & \\
\hline \multicolumn{7}{|l|}{ Gouty arthritis } \\
\hline No & $39(30.7)$ & $88(69.3)$ & Reference & & Reference & \\
\hline Yes & $3(16.7)$ & $15(83.3)$ & $0.451(0.124-1.649)$ & 0.229 & $1.312(0.213-8.094))$ & 0.770 \\
\hline
\end{tabular}


Table 6 Univariate and multivariate analysis of factors associated with pre-dialysis controlled hypertension upon study completion $(n=145)$ (Continued)

\begin{tabular}{|c|c|c|c|c|c|c|}
\hline \multirow[t]{2}{*}{ Variables } & \multicolumn{2}{|c|}{$\begin{array}{l}\text { Patients with pre-dialysis controlled } \\
\text { hypertension on final visit } \\
\text { Number (\%) }\end{array}$} & \multirow[t]{2}{*}{$\begin{array}{l}\text { Univariate analysis } \\
\text { OR }(95 \% \mathrm{Cl})\end{array}$} & \multirow[t]{2}{*}{$\begin{array}{l}p \text { - } \\
\text { value }\end{array}$} & \multirow[t]{2}{*}{$\begin{array}{l}\text { Multivariate } \\
\text { analysis } \\
\text { OR (95\% Cl) }\end{array}$} & \multirow[t]{2}{*}{$\begin{array}{l}p^{-} \\
\text {value }\end{array}$} \\
\hline & Yes & No & & & & \\
\hline \multicolumn{7}{|c|}{ Others comorbidities ${ }^{a}$} \\
\hline No & $26(25)$ & $78(75)$ & Reference & & Reference & \\
\hline Yes & $16(39)$ & $25(61)$ & $1.920(0.890-4.141)$ & 0.096 & $1.865(0.690-5.041)$ & 0.219 \\
\hline \multicolumn{7}{|l|}{ ACE-I } \\
\hline No & $39(29.3)$ & $94(70.7)$ & Reference & & & \\
\hline Yes & $3(25)$ & $9(75)$ & $0.803(0.206-3.127)$ & 0.752 & & \\
\hline \multicolumn{7}{|l|}{ ARB } \\
\hline No & $31(28.4)$ & $78(71.6)$ & Reference & & & \\
\hline Yes & $11(30.6)$ & $25(69.4)$ & $1.107(0.487-2.519)$ & 0.808 & & \\
\hline \multicolumn{7}{|l|}{$\mathrm{CCB}$} \\
\hline No & $17(16.7)$ & $85(83.3)$ & Reference & & Reference & \\
\hline Yes & $25(58.1)$ & $18(41.9)$ & $6.296(2.843-13.943)$ & $<0.001$ & $8.988(3.140-25.728)$ & $<0.001$ \\
\hline \multicolumn{7}{|l|}{ Alpha antagonist } \\
\hline No & $40(28.8)$ & $99(71.2)$ & Reference & & & \\
\hline Yes & $2(33.3)$ & $4(66.7)$ & $1.237(0.218-7.027)$ & 0.810 & & \\
\hline \multicolumn{7}{|l|}{ Beta antagonist } \\
\hline No & $28(27.2)$ & $75(72.8)$ & Reference & & & \\
\hline Yes & $14(33.3)$ & $28(66.7)$ & $1.339(0.617-2.906)$ & 0.460 & & \\
\hline \multicolumn{7}{|l|}{ Diuretics } \\
\hline No & $34(32.7)$ & 70 (67.3) & Reference & & Reference & \\
\hline Yes & $8(19.5)$ & $33(80.5)$ & 0.499 (0.208-1.196) & 0.119 & $0.349(0.108-1.132)$ & 0.080 \\
\hline \multicolumn{7}{|c|}{ Other combination of antihypertensives } \\
\hline No & $36(27.7)$ & $94(72.3)$ & Reference & & & \\
\hline Yes & $6(40)$ & $9(60)$ & $1.741(0.578-5.241)$ & 0.324 & & \\
\hline \multicolumn{7}{|l|}{ Type of therapy } \\
\hline Mono-therapy & $24(30.4)$ & $55(69.6)$ & Reference & & & \\
\hline Multi-therapy & $18(27.3)$ & $48(72.7)$ & $0.859(0.417-1.772)$ & 0.681 & & \\
\hline \multicolumn{7}{|l|}{ Statins } \\
\hline No & $12(30)$ & $28(70)$ & Reference & & & \\
\hline Yes & $30(28.6)$ & $75(71.4)$ & $0.933(0.420-2.073)$ & 0.865 & & \\
\hline \multicolumn{7}{|l|}{ Phosphate binders } \\
\hline No & $5(27.8)$ & $13(72.2)$ & Reference & & & \\
\hline Yes & $37(29.1)$ & $90(70.9)$ & $1.069(0.356-3.212)$ & 0.906 & & \\
\hline
\end{tabular}

Analysis: Univariate and Multivariate binary logistic regression analysis. All variables with $p$-value $<0.25$ will be included in the multivariate analysis. OR Odds ratio, Cl confidence interval, BMI Body mass index, NGO Non-governmental organization, ${ }^{a}$ Other comorbidities: Blood clots, depression, asthma, osteoarthritis, pregnancy losses/birth defects and osteoporosis. ACE-I Angiotensin converting enzyme inhibitors, ARB Angiotensin receptor blocker, CCB Calcium channel blocker

\section{Conclusion}

Our study revealed a positive association between predialysis controlled hypertension among euvolemic hypertensive patients and prescription of CCBs. However, the results of the current study should be interpreted with the major limitations of limited sample size and lack of information about patients' adherence with antihypertensive medications and life style interventions. A large multi-center prospective study is recommended to confirm the present findings. 


\section{Study limitations}

The findings of the present study need to be interpreted with caution since it is limited to only 6 months follow up. Nevertheless, a multicenter study with a large sample size and longer follow-up time is needed to confirm the findings of the current study. Furthermore, some other factors that affect blood pressure control such as salt intake, exercise, etc. were not assessed in this study. As the study was carried out in Kelantan, Malaysia, where Malays are the predominant inhabitants. Malaysia is multiethnic country with the three predominate ethnicities i.e. Malays, Chinese and Indians. The results of this study therefore cannot be extended to the whole population of the country.

\section{Acknowledgments}

We are grateful to the Institute of Postgraduate Studies (IPS) of Universiti Sains Malaysia (USM) for the fellowship support [Ref. no. P-FD0011/15(R)].

\section{Funding}

This research received no specific grant from any funding agency in the public, commercial or not-for-profit sectors.

\section{Availability of data and materials}

All data generated or analyzed during this study are included in this current article. The datasets used and/or analyzed during the current study are available from the corresponding author on reasonable request.

\section{Authors' contributions}

All authors (AK, AHK, ASA, SASS, SM, NA, IK) made substantial contributions to the conception and design of this study. AK and AHK made substantial contributions to the acquisition and analysis of the data. AK drafted the manuscript and ASA, SASS, SM, NA and IK were involved in critical revision for important intellectual content. All authors read and approved the final manuscript.

\section{Ethics approval and consent to participate}

Our study was approved by the Human Resource Ethics Committee of Hospital Universiti Sains Malaysia (USM/JEPeM/16020058) which complies with the Declaration of Helsinki. All patients were asked to read and then sign the written consent forms before study participation. All methods were performed in accordance with the relevant guidelines and regulations.

\section{Consent for publication}

Not applicable.

\section{Competing interests}

The authors declare that they have no competing interests. Cover page including all authors affilliations.

\section{Publisher's Note}

Springer Nature remains neutral with regard to jurisdictional claims in published maps and institutional affiliations.

\footnotetext{
Author details

'Discipline of Clinical Pharmacy, School of Pharmaceutical Sciences, Universiti Sains Malaysia, 11800 Penang, Malaysia. ${ }^{2}$ Chronic Kidney Disease Resource Centre, School of Medical Sciences, Health Campus, Universiti Sains Malaysia, 16150 Kubang Kerian, Kelantan, Malaysia. ${ }^{3}$ Department of Pharmacy, Quaid-i-Azam University, Islamabad 45320, Pakistan. ${ }^{4}$ Health Care Biotechnology Department, Atta ur Rahman School of Applied Biosciences, National University of Sciences \& Technology, Islamabad 44000, Pakistan. ${ }^{5}$ Faculty of Pharmacy and Health Sciences, University of Balochistan, Quetta 87300, Pakistan.
}

Received: 3 October 2018 Accepted: 15 March 2019

Published online: 14 May 2019

\section{References}

1. Peter N, Van B, Jula Kl. Hypertension and hemodialysis: pathophysiology and outcomes in adult and pediatric populations. Pediatr Nephrol. 2012;27:339-50.

2. Agarwal R. Hypervolemia is associated with increased mortality among hemodialysis patients. Hypertension. 2010;56:512-7.

3. Blankestijn PJ, Ligtenberg G. Volume-independent mechanisms of hypertension in hemodialysis patients: clinical implications. Semin Dial. 2004:17:265-9.

4. Ichihara A, Hayashi M, Kaneshiro Y, et al. Low doses of losartan and trandolapril improve arterial stiffness in hemodialysis patients. Am J Kidney Dis. 2005;45:866-74.

5. National Kidney Foundation. K/DOQI Clinical practice guidelines for cardiovascular disease in dialysis patients. Am J Kidney Dis. 2005;45:S49S59-S69-S75.

6. Khan A, Khan AH, Adnan AS, Syed Sulaiman SA, Gan SH, Khan I. Management of patient care in hemodialysis while focusing on cardiovascular disease events and the atypical role of hyper-and/or hypotension: a systematic review. Biomed Res Int. 2016;2016:9710965.

7. Moist LM, Port FK, Orzol SM, Young EW, Ostbye T, Wolfe RA, et al. Predictors of loss of residual renal function among new dialysis patients. J Am Soc Nephrol. 2000:11:556-64.

8. Efrati S, Zaidenstein R, Dishy V, Beberashvili I, Sharist M, Averbukh Z, et al. ACE inhibitors and survival of hemodialysis patients. Am J Kidney Dis. 2002;40:1023-9.

9. Suzuki H, Kanno Y, Kaneko K, Kaneko M, Kotaki S, Mimura T, et al. Comparison of the effects of angiotensin receptor antagonist, angiotensin converting enzyme inhibitor, and their combination on regression of left ventricular hypertrophy of diabetes type 2 patients on recent onset hemodialysis therapy. Ther Apher Dial. 2004;8:320-7.

10. London GM, Marchais SJ, Guerin AP, Metivier F, Safar ME, Fabiani F, Froment L. Salt and water retention and calcium blockade in uremia. Circulation. 1990;82:105-13.

11. Kestenbaum B, Gillen DL, Sherrard DJ, Seliger S, Ball A, Stehman-Breen C. Calcium channel blocker use and mortality among patients with end stage renal disease. Kidney Int. 2002;61:2157-64.

12. Brown MJ, Palmer CR, Castaigne A, de Leeuw PW, Mancia G, Rosenthal T, et al. Morbidity and mortality in patients randomised to double-blind treatment with a long-acting calcium-channel blocker or diuretic in the international Nifedipine GITS study: intervention as a goal in hypertension treatment (INSIGHT). Lancet. 2000;356:366-72.

13. Psaty BM, Heckbert SR, Koepsell TD, Siscovick DS, Raghunathan TE, Weiss NS, et al. The risk of myocardial infarction associated with antihypertensive drug therapies. JAMA. 1995;274:620-5.

14. Hansson L, Hedner T, Lund-Johansen P, Kjeldsen SE, Lindholm LH, Syvertsen JO, et al. Randomised trial of effects of calcium antagonists compared with diuretics and $\beta$-blockers on cardiovascular morbidity and mortality in hypertension: the Nordic diltiazem (NORDIL) study. Lancet. 2000;356:359-65.

15. Hansson L, Zanchetti A, Carruthers SG, Dahlöf B, Elmfeldt D, Julius S, et al. Effects of intensive blood-pressure lowering and low-dose aspirin in patients with hypertension: principal results of the hypertension optimal treatment (HOT) randomised trial. Lancet. 1998;351:1755-62.

16. Estacio RO, Jeffers BW, Hiatt WR, Biggerstaff SL, Gifford N, Schrier RW. The effect of nisoldipine as compared with enalapril on cardiovascular outcomes in patients with non-insulin-dependent diabetes and hypertension. N Engl J Med. 1998;338:645-52.

17. Tuomilehto J, Rastenyte D, Birkenhäger WH, Thijs L, Antikainen R, Bulpitt CJ, et al. Effects of calcium-channel blockade in older patients with diabetes and systolic hypertension. N Engl J Med. 1999;340:677-84.

18. Borhani NO, Mercuri M, Borhani PA, Buckalew VM, Canossa-Terris M, Carr AA, et al. Final outcome results of the multicenter Isradipine diuretic atherosclerosis study (MIDAS): a randomized controlled trial. JAMA. 1996;276:785-91.

19. BAKRIS GL. Calcium abnormalities and the diabetic, hypertensive patient: implications of renal preservation. In: Epstein M, editor. Calcium Antagonists in Clinical Medicine. Philadelphia: Hanley \& Belfus; 1992. p. 367-438.

20. Bakris GL, Standley PR, Palant CE, Walsh MF, Sowers JR. Analogy between endothelial/mesangial cell and endothelial/vascular smooth muscle cell interactions. Endocrinol Vasculature. 1996:341-55. 
21. Shultz PJ, Raij L. Inhibition of human mesangial cell proliferation by calcium channel blockers. Hypertension. 1990;15:176.

22. K/DOQI Workgroup. K/DOQI clinical practice guidelines for cardiovascular disease in dialysis patients. Am J Kidney Dis. 2005;45:S1-S153.

23. Wabel P, Moissl U, Chamney P, Jirka T, Machek P, Ponce P, et al. Towards improved cardiovascular management: the necessity of combining blood pressure and fluid overload. Nephrol Dial Transplant. 2008;23:2965-71.

24. Wieskotten $\mathrm{S}$, Heinke S, Wabel P, Moissl U, Becker J, Pirlich M, et al. Bioimpedance-based identification of malnutrition using fuzzy logic. Physiol Meas. 2008;29:639.

25. Tai R, Ohashi Y, Mizuiri S, Aikawa A, Sakai K. Association between ratio of measured extracellular volume to expected body fluid volume and renal outcomes in patients with chronic kidney disease: a retrospective single-center cohort study. BMC Nephrol. 2014;15:189.

26. National Kidney Foundation. KDOQI clinical practice guideline for hemodialysis adequacy: update. Am J Kidney Dis. 2015:66:884-930.

27. Inrig J, Oddone E, Hasselblad V, Gillespie B, Patel UD, Reddan D, Toto R, Himmelfarb J, Winchester JF, Stivelman J, Lindsay RM, Szczech LA. Association of intradialytic blood pressure changes with hospitalization and mortality rates in prevalent ESRD patients. Kidney Int. 2007;71:454-61.

28. Koshy S, Bakris GL. Therapeutic approaches to achieve desired blood pressure goals: focus on calcium channel blockers. Cardiovasc. Drugs Ther. 2000;14:295-301

29. Tepel M, Giet MV, Park A, Zidek W. Association of calcium channel blockers and mortality in haemodialysis patients. Clin Sci (Lond). 2002:103:511-5.

30. London GM, Pannier B, Guerin AP, Marchais SJ, Safar ME, Cuche JL. Cardiac hypertrophy, aortic compliance, peripheral resistance, and wave reflection in end-stage renal disease. Comparative effects of ACE inhibition and calcium channel blockade. Circulation. 1994;90:2786-96.

31. Inrig JK. Antihypertensive agents in hemodialysis patients: a current perspective. Semin Dial. 2010;23(3):290-7 Wiley Online Library.

32. Ha S-K, Park HS, Kim SJ, Park CH, Kim DS, Kim HS. Prevalence and patterns of left ventricular hypertrophy in patients with predialysis chronic renal failure. J Korean Med Sci. 1998;13:488-94.

33. Harnett J, Parfrey P, Griffiths S, Gault M, Barre P, Guttmann R. Left ventricular hypertrophy in end-stage renal disease. Nephron. 1988:48:107-15.

34. Suzuki H, Saruta T. Effects of calcium antagonist, benidipine, on the progression of chronic renal failure in the elderly: a 1-year follow-up. Clin Exp Hypertens. 2001;23:189-201.

35. Zucchelli P, Zuccala A, Borghi M, Fusaroli M, Sasdelli M, Stallone C, Sanna G, Gaggi R. Long-term comparison between captopril and nifedipine in the progression of renal insufficiency. Kidney Int. 1992;42:452-8.

36. Tuomilehto J, Rastenyte D, Birkenhager W, Thijs L, Antikainen R, Bulpitt C, Fletcher A, Forette F, Goldhaber A, Palatini P, Sarti C, Fagard R. For the systolic hypertension in Europe trial: effects of calcium-channel blockade in older patients with diabetes and systolic hypertension. N Engl J Med. 1999; 340:7677-84.

37. Saruta T, Suzuki H. Efficacy of manidipine in the treatment of hypertension with renal impairment: a multicenter trial. Am Heart J. 1993:125:630-4

38. Baumelou A, Bentchikou A, Vray M, Jourdan I, Eugene M. Nitrendipine in patients with renal disease. J Cardiovasc Pharmacol. 1987;9(Suppl 4):S174-S7.

39. Bühler FR. Calcium antagonists as first-choice therapy for low-renin essential hypertension. Kidney Int. 1989;36:295-305.

40. Mimran A, Ribstein J. Angiotensin-converting enzyme inhibitors versus calcium antagonists in the progression of renal diseases. Am J Hypertens. 1994;7(9 Pt 2):73S-81S.

41. Staessen JA, Thijs L, Fagard RH, Birkenhäger WH, Arabidze G, Babeanu S, et al. Calcium channel blockade and cardiovascular prognosis in the European trial on isolated systolic hypertension. Hypertension. 1998;32:410-6.

42. Lever AF, Ramsay LE. Treatment of hypertension in the elderly. J Hypertens. 1995;13:571-9

43. Tatti P, Pahor M, Byington RP, Di Mauro P, Guarisco R, Strollo G, et al. Outcome results of the Fosinopril versus amlodipine cardiovascular events randomized trial (FACET) in patients with hypertension and NIDDM. Diabetes Care. 1998;21:597-603.

\section{Ready to submit your research? Choose BMC and benefit from:}

- fast, convenient online submission

- thorough peer review by experienced researchers in your field

- rapid publication on acceptance

- support for research data, including large and complex data types

- gold Open Access which fosters wider collaboration and increased citations

- maximum visibility for your research: over $100 \mathrm{M}$ website views per year

At BMC, research is always in progress.

Learn more biomedcentral.com/submissions 